\title{
Portland-Milwaukie Light Rail Transit Project: Managing Growth Sustainably through Transit Alternatives
}

\author{
Stephan Schmidt and Kayla Gordon \\ Second-year MCRP students, Cal Poly.
}

\begin{abstract}
Schmidt and Gordon discuss the Portland-Milwaukie Light Rail Transit Project which will connect previously underserved areas to Portland's downtown core. Unique in its citizen-driven planning process it will stimulate the regional economy and enhance the quality of life through environmentally-conscious development.
\end{abstract}

$E_{0}^{c o n t o n s}$ coMobility aims to enhance transportation options in order to reduce resource use and promote public health for a better quality of life. As communities grow, there is potential for that growth to occur in a variety of ways. EcoMobility principles ensure that sustainability and equity are included in the planning process.

The Portland metropolitan region's South Corridor is expected to add one million residents and 100,000 jobs by 2030, putting stress on an already-burdened transportation infrastructure. To alleviate congestion, add transit alternatives and promote sustainable development, Tri-Met has initiated the Portland-Milwaukie Light Rail Transit Project. Driven by citizen engagement and defined by innovative design features, this project will allow growth to occur in a manageable way throughout the region, while supporting the local economy and increasing transit access to previously underserved communities.

By incorporating active and public transportation routes and restricting access of private vehicles on the bridge, Portland has demonstrated how its innovative transportation policy can lead the way for cities across the globe.

\section{The City Context: Portland}

The City of Portland is located in the northern portion of the State of Oregon, in the United States. It is the largest city and county seat of Multnomah County. Renowned for its bicycle- and pedestrian-friendly infrastructure and progressive land-use policies, the city is the 28th largest in the United States with an estimated population of 603,106

This article was adapted by permission from a case-study done by the authors during their internship at ICLEI -Local Governments for Sustainability in 2013, and available at http://www.iclei.org/fileadmin/ PUBLICATIONS/Case_Studies/ICLEI_cs_163_Portland_2013.pdf.

Acknowledgements: The authors thank John Fall (Tri-Met), Sunny Kodukula (ICLEI Global Coordinator for EcoMobility), and Melissa Higbee (ICLEI-USA Intern Coordinator). FOCUS thanks ICLEI for permission to reproduce this material. residents, as of 2012. It is urban in nature, with 1,689 people per square kilometer, ranking 14th out of American metropolitan areas in density.

The Tri-County Metropolitan Transportation District of Oregon (Tri-Met) is the public agency that operates the light and commuter rail and bus system in the metropolitan area. The light rail system, known as the MAX, carries approximately 127,000 people daily across five lines and is one of the most heavily used light rail lines in the U.S. As a whole, Tri-Met's offerings carry more people than any other transportation system of its size in the country.

The Portland Bureau of Transportation (PBOT) is also an actor in the city's transportation environment. PBOT operates the SmartTrips program aimed at encouraging all citizens to utilize alternative forms of personal and recreational transit. Select initiatives include Senior Strolls and Women on Bikes. The agency is also responsible for the bicycle infrastructure in the city.

The City of Milwaukie, located south of Portland, serves as a suburb with approximately 20,000 residents. The downtown is currently undergoing a revival, as new housing and commercial developments are under construction or planned, spurred in part by news of the new transit connection to Portland.

\section{The Light Rail Expansion in Portland}

In 1999, the City of Portland partnered with Tri-Met and other organizations to study transportation options in the South Corridor of the metropolitan area. A congested thoroughfare, McLoughlin Boulevard, currently dominates this corridor, which mostly carries commuters from Milwaukie and south Portland to and from downtown Portland. The initial proposals included river transit, high occupancy vehicle lanes, toll lanes, bus rapid transit and a commuter rail line. Light Rail was initially not considered as an alternative but due to active community participation in 
the impacted neighborhoods, it was eventually selected as the Locally Preferred Alternative.

The first phase of the project in the South Corridor was completed in 2009 and provided light rail service from suburban Clackamas in the southeast of the region to Portland State University via the MAX Green Line. The Portland-Milwaukie Light Rail (PMLR) Transit Project comprises phase two of the project and will link downtown Portland to northern Clackamas County in the south of the region, traversing Portland State University, the Oregon Health \& Science University, downtown Milwaukie and a new bridge to be used exclusively for active and public transportation. This will create the new Orange line in the MAX system.

The expansion of transportation in Portland is intended to increase livability and economic development throughout the metropolitan region. The South Corridor is expected to add one million people and 100,000 jobs by 2030 . This project will allow development of the area to occur in a sustainable way and serve communities previously neglected by alternative transit options. Speaking to the crowd at the formal dedication ceremony of FTA funding approval, administrator Peter Rogoff posed a question: "Is Portland going to plan for its growth, or be overwhelmed by it?" This project is an opportunity to plan for the region's growth.

Sustainability is a major focus of this project, and protecting species and restoring wildlife and riparian habitat in the project area is critical to the mission. Public art installations associated with the project are meant to focus on lowimpact development principles and contribute sensitivity as well as creativity to the public realm. A unique feature, referred to as an "eco-track," will bring European-style vegetated rail tracks to Portland for the first time at the Lincoln Street/SW 3rd Avenue station and further beautify the right-of-way while providing ecological benefits.

As with any large infrastructure project, challenges were inherent in the planning stage of the PMLR. In the summer of 2010, Federal Transit Administration funding was reduced from 60 to 5 percent, leaving Tri-Met approximately $\$ 140$ million short of funding. In order to stay within the new budget, the scope of the project had to be reduced.

Two important decisions had to be made regarding the orientation of the light rail path. First was the placement of the bridge. To facilitate this decision, the Willamette River Crossing Partnership Committee was created and consisted of former Portland Mayor Vera Katz and project partners and institutions, businesses and neighborhood representatives from both sides of the river. In May 2008, the committee recommended the current alignment, which begins at OHSU's future South Waterfront campus and then crosses the river to the east bank to SE Sherman Avenue near the Portland Opera rehearsal and administrative space.

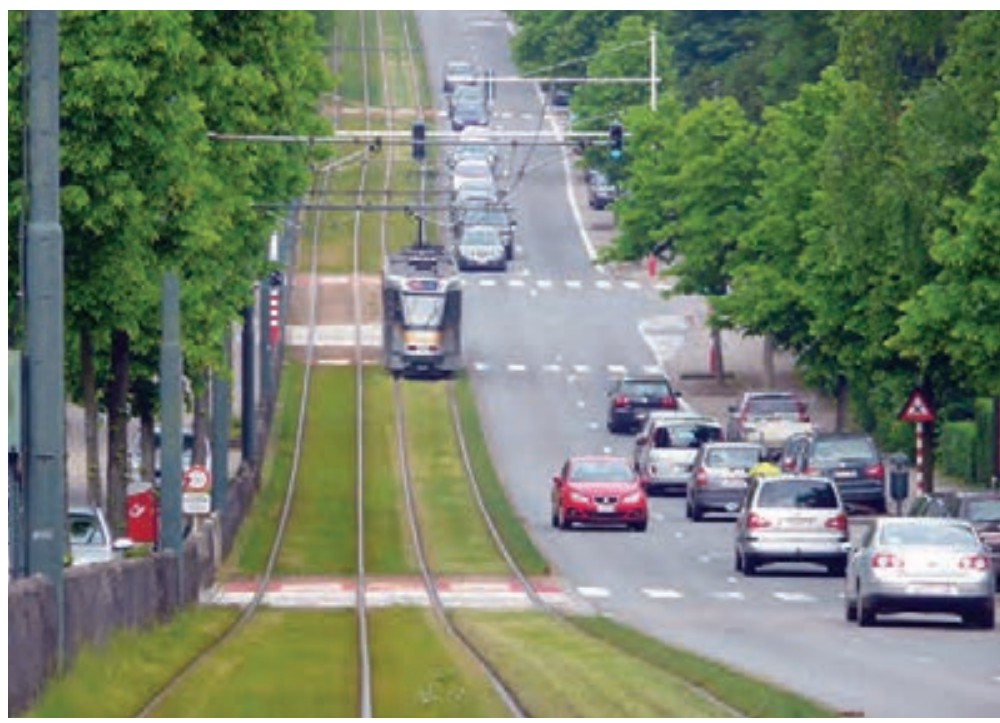

Figure 1: The Eco-Track at Lincoln and SW 3rd Avenue may resemble this track in Belgium. (source: http:// citytransport.info/Digi/P1090720a.jpg.)

Figure 2: The Portland-Milwaukie Light Rail Project. Route map from the Locally Prefered Alternative. (source: http:// trimet.org/pdfs/pm/LPA_Map.pdf)

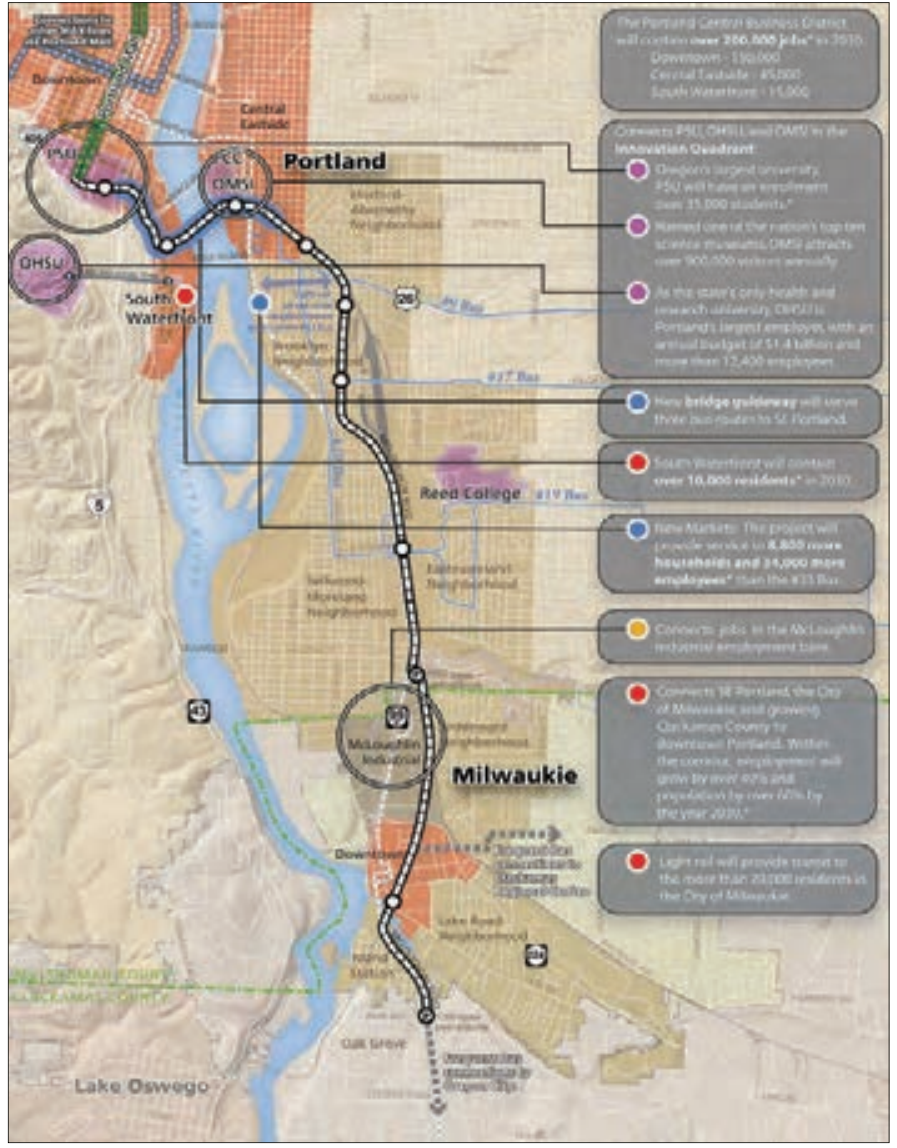




\section{Lessons Learned}

Many of the major decisions made for the PMLR involved a flexible and interactive process with the citizen advisory committee, technical advisory committee, steering committees, a safety and security task force, and the project management group. These groups were comprised of local residents, business leaders, representatives from public institutions and community groups, and various professional staff members. Throughout the project development, the various committees learned about and toured the proposed alignments, participated in public meetings, and reviewed the technical findings. The steering committee, comprised of elected officials from the partner agencies, made all final policy decisions regarding the project. The local communities also stayed informed throughout the decision-making process through open houses, community presentations, newsletters, ads, website updates, Citizen Advisory Committee meetings, and Station Area Planning meetings.

Throughout the project, there was significant controversy over the $\$ 1.495$ billion price tag for the project, making it the most expensive surface-running rail project in the country. This controversy deepened when the federal funding match was reduced from $60 \%$ to $50 \%$ of the project's total cost, and Tri-Met had to ultimately reduce the scope of the project. Many people believed the construction of the PMLR project was contributing to Tri-Met's financial crisis; however, Tri-Met's share of the entire project is less than $5 \%$ of the total project budget. Most of the construction and operating costs are funded by a passed payroll tax rate increase from 2005, which are funds dedicated specifically to new transit services. Accurate and timely public notification of such funding decisions is essential for a successful transit project.

An active and early public involvement process ensured that the PMLR project was the right project, in the right place, for the right price. Other regions looking to explore similar options should make sure to consider all routing options and locations before starting the project, and involve all affected communities as part of a regional collaboration process.

The successful outcomes of the PMLR are the result of an extensive public involvement process, which began during the initial phases of the project development. In 1999, a series of public meetings resulted in strong support for transit alternatives to relieve traffic congestion in the South Corridor. In 2002, neighborhoods along the corridor insisted upon the addition of light rail as an option, and in 2003 the steering committee selected light rail as the Locally Preferred Alternative after extensive public testimony and technical recommendations from the Environmental Impact Statement.
In 2011, the project's Environmental Impact Statement won FTA's 2011 "Outstanding Achievement Award for Excellence in Environmental Document Presentation", which is given to agencies that provide "truly useful" information to the public about a project, and that display the benefits, impacts and costs of the overall project in a way that is easily understood by all stakeholders and the public.

\section{Sources}

Tri-County Metropolitan Transportation District of Oregon (TriMet). 2008. Portland-Milwaukie Light Rail Project Supplemental Draft Environmental Impact Statement. http://trimet.org/pdfs/pm/sdeis/PMLR_SDEIS_Chapter1.pdf May; accessed August 20, 2013.

2011. FTA recognizes Portland-Milwaukie Light Rail Project for outstanding achievement. http://trimet.org/ news/releases/oct7-fta-award.htm; accessed August 20, 2013.

2012. About the Project. http://trimet.org/pm/abouttheproject/index.htm; accessed August 19, 2013.

2012. About the Project. 2012. http://trimet.org/pm/ abouttheproject; accessed August 20, 2013.

2012. Portland-Milwaukie Light Rail Bridge Fact Sheet. http://trimet.org/pdfs/pm/Fact-sheets-timelines/PMLR_ Bridge_Fact_Sheet_August2012.pdf; accessed August 20, 2013.

2012. Route and Stations. http://trimet.org/pm/routeandstations/index.htm; accessed August 20, 2013.

2013. Facts About TriMet. April 2013. http://trimet.org/ pdfs/publications/factsheet.pdf; accessed August 19, 2013.

2013. Portland-Milwaukie: A vital transportation link. http://trimet.org/pdfs/publications/pmlr-fact-sheet.pdf; accessed August 20, 2013.

2013. Steering Committee. http://trimet.org/pdfs/pm/ Steering_Committee/April_2013/2013April_Steering_ Comm.pdf; accessed August 20, 2013.

2013. What Are the Options? http://trimet.org/choices/ what-are-the-options.htm; accessed August 20, 2013.

2013. Economic Benefits. http://trimet.org/pm/economicbenefits/; accessed August 20, 2013.

2013. Portland-Milwaukie Light Rail Transit project reaches 50 Percent Complete Milestone. http://news. trimet.org/2013/07/portland-milwaukie-light-rail-transitproject-reaches-50-complete-milestone; accessed August 20, 2013.

Federal Transit Administration. 2013. Portland-Milwaukie Light Rail Transit complete profile. http://www.fta.dot. gov/documents/OR_Portland_Milwaukie_LRT_com- 
plete_profile.pdf; accessed August 20, 2013.

Nelson, Jonathan. 2009. With light rail on the way, downtown Milwaukie due for a makeover. Clackamas County News. http://www.oregonlive.com/clackamascounty/index.ssf/2009/08/with_light_rail_on_the_way_dow.html, accessed August 19, 2013.

Oregon Metro. 2013. South Corridor Project History. http:// www.oregonmetro.gov/index.cfm/go/by.web/id=24981; accessed August 19, 2013.

Portland-Milwaukie Light Rail Project public participation and decision-making process. http://www.oregonmetro.gov/index.cfm/go/by.web/id=24964; accessed August 20, 2013.

Rose, Joseph. 2011. Feds Say Portland-Milwaukie MAX Line Settle for 50-50 Funding. The Oregonian. http:// www.oregonlive.com/portland/index.ssf/2010/07/feds say_portland-milwaukie_ma.html; last modified June 24, 2011; accessed August 20, 2013.

Transportation Choices. "Lessons Learned from Portland's Newwest Rail Line." Accessed August 20, 2013. https:// www.transportationchoices.org/blog/lessons-learnfrom-portlands-newest-rail-line

United States Census Bureau. 2013. State \& County QuickFacts: Milwaukie, Oregon. http://quickfacts.census.gov/qfd/states/41/4148650.html; accessed August 19, 2013.

U.S. Department of Transportation Federal Transit Administration. 2013. New Starts Fact Sheet. http://www.fta. dot.gov/12304_2607.html; accessed August 20, 2013.

Wagner, Zef. 2011. Lessons Learned from Portland's Newest Line. https://www.transportationchoices.org/blog/ lessons-learn-from-portlands-newest-rail-line; accessed August 20, 2013.

YouTube. 2012. Federal Funding For the Portland-Milwaukie Light Rail. https://www.youtube.com/watch?v= uL-uWhCAX-8; accessed August 20, 2013. 